\title{
Cost of early-stage mycosis fungoides treatments in Spain
}

This article was published in the following Dove Press journal:

ClinicoEconomics and Outcomes Research

\author{
Pablo Luis Ortiz- \\ Romero (1) \\ Octavio Servitje (iD $^{2}$ \\ María Teresa Estrach ${ }^{3}$ \\ Rosa María Izu-Belloso ${ }^{4}$ \\ Ricardo Fernández-de- \\ Misa (D) $^{5}$ \\ Fernando Gallardo ${ }^{6}$ \\ Noemí López-Martínez ${ }^{7}$ \\ Alejandro Pérez-Mitru ${ }^{7}$ \\ 'Dermatology Department, Hospital 12 \\ de Octubre, Institute I+12, Medical \\ School, University Complutense, \\ CIBERONC, Madrid, Spain; \\ ${ }^{2}$ Dermatology Department, Hospital \\ Universitari de Bellvitge, IDIBELL, \\ L'Hospitalet de Llobregat, Barcelona, \\ Spain; ${ }^{3}$ Dermatology Department, \\ Hospital Clínic, IDIBAPS, Universitat de \\ Barcelona, Barcelona, Spain; \\ ${ }^{4}$ Dermatology Department, Hospital de \\ Basurto, Bilbao, Spain; ${ }^{5}$ Department of \\ Dermatology and Research Unit, Hospital \\ Universitario Nuestra Señora de \\ Candelaria, Santa Cruz de Tenerife, Spain; \\ ${ }^{6}$ Dermatology Department, Parc de Salut \\ Mar-Hospital del Mar, Barcelona, Spain; \\ ${ }^{7}$ Oblikue Consulting, Barcelona, Spain
}

\begin{abstract}
Aim: To identify the most common therapeutic options for the treatment of early-stage mycosis fungoides in Spain, quantify their associated healthcare resource use and costs.

Methods: After reviewing the literature, a panel of 6 Spanish clinical dermatologists validated the treatments and healthcare resource use through a structured questionnaire. Individual responses were collected, analyzed and presented into a face-to-face meeting in order to reach a consensus. Cost categories considered were: drug acquisition and administration, photo/radiotherapy session and maintenance, clinical follow-up visits and laboratory tests. Costs were expressed in euros from 2018. The Spanish National Health System perspective was considered, taking into account direct health costs and time horizons of 1, 3 and 6 months.

Results: Costs for the skin-directed treatments (SDT) assessed at 1, 3 and 6 months, were: Topical carmustine [€6,593.36, €19,780.09 and €27,592.78]; Phototherapy with psoralens and ultraviolet A light (PUVA) [€1,098.68, €2,999.99 and €3,187.60]; Narrow-band ultraviolet B phototherapy $[€ 1,657.47, € 4,842.10$ and $€ 4,842.10]$; Total skin electron beam therapy (TSEBT) [€6,796.45, €7,913.34 and €7,913.34]. Cost for topical corticosteroids, being considered an adjuvant option, were $€ 17.16, € 51.49$ and $€ 102.97$. Costs for the assessed systemic treatments alone or in combination with SDT at 1, 3 and 6 months, were: Systemic retinoids $[€ 2,026.03, € 5,206.63$ and $€ 7,426.42]$; Systemic retinoids + PUVA phototherapy [€3,066.50, $€ 8,271.26$ and $€ 10,046.58]$; Interferon alfa + PUVA phototherapy $[€ 1,541.09, € 5,167.57$ and $€ 6,404.55]$.
\end{abstract}

Conclusion: According to the Spanish clinical practice, phototherapies in monotherapy were the treatments with the lowest associated costs regardless of the time horizon considered. TSEBT turned out as the treatment with the highest associated costs when considering 1 month. However, while considering 3 and 6 months the treatment with the highest associated costs was topical carmustine. The results of this analysis may provide critical information to measure the disease burden, to detect unmet medical needs and to advocate towards better treatments for this rare disease.

Keywords: health care costs, health resources, mycosis fungoides, lymphoma, T-cell, cutaneous, surveys and questionnaires, Spain

\section{Introduction}

Cutaneous T-cell lymphomas (CTCL) are a heterogeneous group of diseases that represent between $1-4 \%$ of cases of non-Hodgkin lymphomas. ${ }^{1-5}$ CTCLs are characterized by the primary infiltration of malignant T cells in the skin without evidence of extracutaneous disease at the time of diagnosis. ${ }^{1,6,7}$

Mycosis fungoides (MF) represents between $50-70 \%$ of cases of CTCL, ${ }^{3,8-11}$ being classified as a rare disease. ${ }^{12,13}$ Although prevalence is difficult to
Correspondence: Alejandro Pérez-Mitru Oblikue Consulting, C/Comte D'urgell, 240, 2-D, Barcelona 08036, Spain

Tel +3493252I 377

$\mathrm{Fax}+34937379984$

Email alejandro.perez@oblikue.com 
determine, the age-adjusted incidence of MF is estimated to be between 0.12 and 0.55 cases per 100,000 inhabitants. ${ }^{14-17}$ The low incidence rate of CTCLs means it is essential to create multicenter records in order to shed light on the characteristics of patients affected by this group of diseases, to describe their state of health and clinical burden and to have a better understanding of their management and prognosis. ${ }^{18,19}$ This has led to the Spanish Academy of Dermatology and Venerology (AEDV) setting up a registry of patients with primary skin lymphomas. It recently published the results from its first year in operation: by December 2017, the registry contained information on 639 patients with primary skin lymphomas from 16 University Hospitals. Among the 348 recorded MF patients, the most common diagnosis was classical MF (77.3\%), most of them (83.6\%) presented early stages of the disease (IA-IIA). ${ }^{20}$

In most cases, MF initially presents as an indolent condition with slow progression that tends to start with a patch phase, progressing in some patients to infiltrated plaques and finally evolving into a tumoral phase. ${ }^{1,21-23}$ The prognosis depends on the disease stage as determined by the International Society for Cutaneous Lymphomas (ISCL) and the European Organization for Research and Treatment of Cancer (EORTC). ${ }^{6,24}$

As the disease progresses, a detrimental effect on survival has been observed among MF patients. ${ }^{25-29}$ Although patients with limited T1 stage MF present a similar life expectancy to the control populations, ${ }^{25,27}$ generally patients with MF present accumulated survival rates significantly lower compared to the healthy population matched by age and sex. ${ }^{25}$

Treatment strategies for MF can be split into two categories: skin-directed treatments (SDT) and systemic treatments including biological response modifiers, single or multiple chemotherapies, epigenetic therapies, monoclonal antibodies and hematopoietic stem cell transplantation. ${ }^{11,30,31}$ Despite the availability of multiple treatment options, none of these may be considered as standard. ${ }^{32}$ Patients with limited-stage disease are usually treated with SDT, while patients with advanced stage MF require a broader multidisciplinary approach involving various combinations of SDT, biological response modifiers and systemic chemotherapy. ${ }^{11,30-32}$

MF presents a significant clinical burden for patients with this rare disease. Patients not only feel overwhelmed by the physical symptoms of the disease but also suffer from sleep problems because of itching, ${ }^{8,33}$ and experience a significant emotional impact caused by frustration and rejection of their disease. ${ }^{33,34}$ MF has an impact on patients' functional capability and the ability to carry out daily activities. It also has a negative effect on patients' productivity, causing work absenteeism or interfering with their productivity. ${ }^{8}$

In financial terms, MF involves a significant burden both to patients as well as to healthcare systems. Although patients with advanced stage MF incur higher healthcare costs than patients at the early stages, it has been shown that MF patients with less severe stages may also require high use of healthcare resources because of numerous visits to outpatient care centers and pharmacy departments. ${ }^{35-37}$ In addition, treating MF may be a social economic strain because of transport direct costs and indirect costs associated with loss of productivity, ${ }^{38}$ all depending on their geographic location, the type of treatment and the characteristics of the healthcare system.

This, together with the lack of financial studies in Spain on this rare disease, has motivated this study with the aim of identifying the therapeutic alternatives most commonly used in Spain for managing patients with earlystage MF, to determine their associated healthcare resources use and to quantify their associated costs.

\section{Materials and methods Study design}

Firstly, a structured review of medical literature was carried out to determine the available clinical and financial evidence on CTCLs and MF, and to draw up a structured questionnaire with the aim of defining the most commonly used treatment alternatives in Spain for managing patients with early stages of MF, to determine their healthcare resources use and to quantify their associated costs. A panel of 6 clinical dermatology experts from the Spanish setting with a wealth of experience in managing CTCL and MF was put together. After completing and returning the questionnaires, the individual responses were assessed and grouped to obtain data considered in the analysis. A face-to-face meeting was set up to present and validate the responses obtained and to reach consensus on the grouped responses. The identity of the members of the expert panel was kept secret by the team responsible for the research until the face-to-face meeting (Figure 1).

\section{Therapeutic options}

From the evidence available, the main treatments used in Spanish clinical practice for early-stage MF are: 


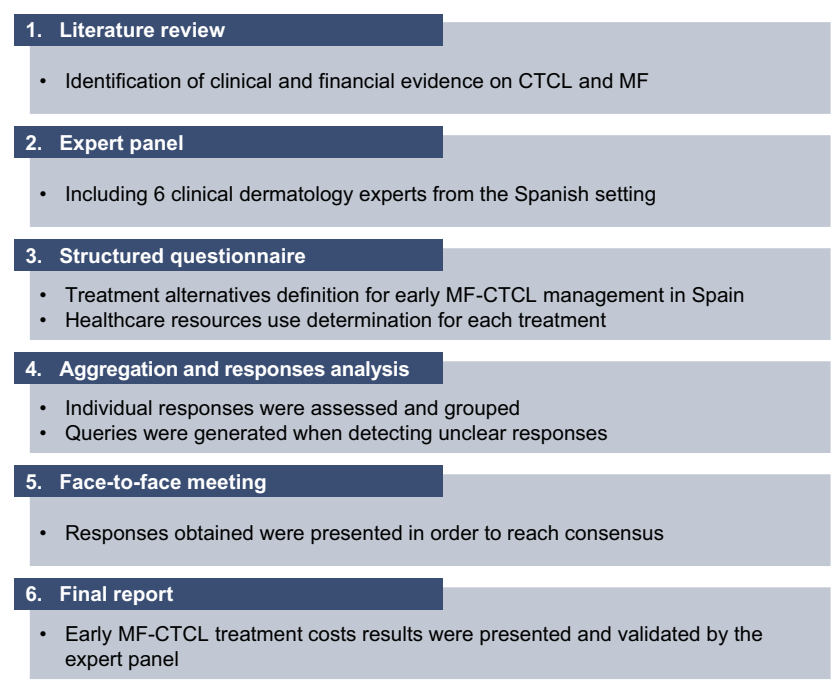

Figure I Study diagram.

Abbreviations: CTCL, cutaneous T-cell lymphomas; MF, mycosis fungoides.

phototherapy with psoralen and ultraviolet A light (PUVA), phototherapy with narrowband ultraviolet B light (NB-UVB), total skin electron beam therapy (TSEBT), topical corticosteroids, systemic retinoids, a combination of PUVA phototherapy with systemic retinoids or interferon alfa (IFN $\alpha$ ), as well as, to a lesser extent, topical carmustine-based chemotherapy.

\section{Questionnaire}

The questionnaire consisted of a total of 72 questions requested as qualitative questions to confirm data from medical literature, quantitative questions, and open-ended questions. The numerical responses were grouped and the average data, standard deviation, median, minimum and maximum data were estimated. The qualitative responses were grouped according to the following criteria: unanimous response (the whole expert panel $[100 \%]$ in agreement), consensus (at least $83 \%$ of the expert panel gave the same response but without being unanimous), majority (response indicated by a majority of the expert panel, that is between $66 \%$ and $83 \%$ ) and discrepancy (all other possible situations: namely, where the same response was not shared by at least $66 \%$ of the experts panel). All members of the expert panel provided their informed consent to participate in this study and to complete the questionnaire.

\section{Type of analysis}

Treatment cost analysis was carried out from the perspective of the Spanish National Health System. Therefore, the direct healthcare costs were taken into account. The
Spanish expert panel considered that adopting one-year time horizon would not be appropriate for this analysis. During one-year timeframe, different MF-CTCL treatments may be used in combination or alternately. Therefore, according to the most commonly established follow-up timeframes and treatment durations, using time horizons of 1, 3 and 6 months would be the best approach to capture and reflect healthcare resource usage within MF-CTCL patients being managed in the Spanish setting.

\section{Costs}

Cost categories used for analysis were: pharmaceutical costs, administration-related costs, costs for each session of phototherapy or radiotherapy, costs attributable to their maintenance, and costs associated with follow-up visits and laboratory tests. This analysis has only taken into account costs derived from the healthcare resources differentially required by each treatment, excluding any costs attributable to all treatments assessed. For medicinal products dispensed by community pharmacies, retail prices were used, whereas for medicinal products used in the hospital setting, the reported ex-factory prices were used including the Royal Decree-Law 8/2010 deduction. ${ }^{39}$ Vial optimization (ie, residual or non-vial wastage) was taken into account for medicinal products requiring parenteral administration. Unit costs were obtained from tariffs published by the autonomous communities, from the Spanish General Council for the Official College of Pharmacists database and medical literature published in the Spanish setting. ${ }^{40-47}$ All costs are given in euros for the year 2018 (Table 1).

\section{Patient characteristics}

Clinical experts unanimously confirmed that the mean body surface area and mean weight of an adult patient with earlystage MF should be equivalent to the Spanish adult population, namely $1.81 \mathrm{~m}^{2}$ and $72.88 \mathrm{~kg} .{ }^{48}$ In order to be able to estimate the corticosteroids consumption, a baseline body surface area involvement of $11 \%$ (range $2 \%-17 \%$ ) was considered to be representative for an early-stage MF patient. ${ }^{49,50}$ All inputs considered in the current study were available from the literature and validated through an expert panel. Therefore, this study did not require ethical review board or committee approval neither to obtain patient consent.

\section{Use of resources}

\section{Skin-directed treatments}

Topical carmustine

The human and equipment resources involved in the acquisition, management, compounding, monitoring and dispensing 
Table I Unit costs

\begin{tabular}{|c|c|c|c|c|}
\hline \multirow[t]{2}{*}{ Concept } & \multicolumn{3}{|c|}{ Unit cost $(€, 2018)$} & \multirow[t]{2}{*}{ Source } \\
\hline & $\begin{array}{l}\text { Base } \\
\text { case }\end{array}$ & $\begin{array}{l}\text { Minimum } \\
\text { scenario }\end{array}$ & $\begin{array}{l}\text { Maximum } \\
\text { scenario }\end{array}$ & \\
\hline $\begin{array}{l}\text { Pharmaceutical costs } \\
\text { Acitretin OR (mg) } \\
\text { Alitretinoin OR (mg) } \\
\text { Beclomethasone TP (g) } \\
\text { Betamethasone TP (g) } \\
\text { Bexarotene OR (mg) } \\
\text { Carmustine IV (100 mg vial) } \\
\text { Clobetasol TP (g) } \\
\text { Diflorasone TP (g) } \\
\text { Statins OR (tablet) } \\
\text { Fenofibrate OR (tablet) } \\
\text { Fluocinolone TP (g) } \\
\text { Fluticasone TP (g) } \\
\text { IFN } \alpha \text { (MIU) } \\
\text { Isotretinoin OR (mg) } \\
\text { Levothyroxine OR (tablet) } \\
\text { Methylprednisolone TP (g) } \\
\text { Mometasone TP (g) } \\
\text { Triamcinolone TP (g) }\end{array}$ & $\begin{array}{l}0.05 \\
0.96 \\
0.05 \\
0.07 \\
0.14 \\
1,405.00 \\
0.08 \\
0.08 \\
0.11 \\
0.18 \\
0.12 \\
0.15 \\
3.96 \\
0.04 \\
0.04 \\
0.16 \\
0.08 \\
0.30\end{array}$ & $\begin{array}{l}0.04 \\
0.48 \\
0.04 \\
0.05 \\
0.11 \\
1,124.00 \\
0.07 \\
0.06 \\
0.11 \\
0.18 \\
0.04 \\
0.12 \\
3.82 \\
0.04 \\
0.02 \\
0.14 \\
0.08 \\
0.19\end{array}$ & $\begin{array}{l}0.06 \\
1.43 \\
0.08 \\
0.09 \\
0.16 \\
1,686.00 \\
0.10 \\
0.09 \\
0.12 \\
0.22 \\
0.24 \\
0.18 \\
4.11 \\
0.04 \\
0.07 \\
0.19 \\
0.08 \\
0.39\end{array}$ & 40 \\
\hline $\begin{array}{l}\text { Imaging and laboratory } \\
\text { tests } \\
\text { Complete biochemistry } \\
\text { ANA level } \\
\text { Calcium/vitamin D level } \\
\text { Cortisol level } \\
\text { Creatinine level } \\
\text { Liver function test }^{\mathrm{b}} \\
\text { Thyroid function test } \\
\text { Hemogram analysis } \\
\text { Blood triglycerides and } \\
\text { cholesterol levels } \\
\text { Lymphoid phenotype } \\
\text { Phototest/photopatch } \\
\text { Chest X-ray } \\
\text { CT scan of abdomen and } \\
\text { pelvis } \\
\text { Pregnancy test }\end{array}$ & $\begin{array}{l}91.41 \\
27.39 \\
31.07 \\
9.58 \\
2.84 \\
22.92 \\
24.95 \\
4.44 \\
6.91 \\
\\
58.69 \\
85.81 \\
25.97 \\
254.19 \\
8.38\end{array}$ & $\begin{array}{l}29.32 \\
15.00 \\
12.26 \\
6.16 \\
0.48 \\
5.01 \\
15.23 \\
3.25 \\
1.19 \\
\\
24.00 \\
78.00 \\
9.15 \\
62.00 \\
5.00\end{array}$ & $\begin{array}{l}182.88 \\
38.01 \\
42.88 \\
14.00 \\
7.30 \\
63.88 \\
43.32 \\
5.36 \\
15.10 \\
107.06 \\
94.25 \\
84.00 \\
484.88 \\
11.30\end{array}$ & 41 \\
\hline $\begin{array}{l}\text { Visit and clinical } \\
\text { assessments } \\
\text { Specialist consultation, initial } \\
\text { Consultations with } \\
\text { specialist, successive } \\
\text { Ophthalmology review } \\
\text { Following psychiatric review }\end{array}$ & $\begin{array}{l}121.18 \\
86.46 \\
51.55 \\
47.91\end{array}$ & $\begin{array}{l}26.00 \\
25.52 \\
47.00 \\
26.00\end{array}$ & $\begin{array}{l}245.99 \\
150.95 \\
56.09 \\
82.00\end{array}$ & 41 \\
\hline $\begin{array}{l}\text { Treatment consultations } \\
\text { PUVA session } \\
\text { NB-UVB session } \\
\text { TSEB session }\end{array}$ & $\begin{array}{l}87.37 \\
136.08 \\
312.09\end{array}$ & $\begin{array}{l}44.00 \\
44.00 \\
311.26\end{array}$ & $\begin{array}{l}151.96 \\
195.25 \\
312.93\end{array}$ & 41 \\
\hline $\begin{array}{l}\text { Other costs } \\
\text { Parenteral administration } \\
\text { (day hospital) }^{d}\end{array}$ & 30.51 & 19.09 & 41.93 & 42 \\
\hline
\end{tabular}

(Continued)
Table I (Continued).

\begin{tabular}{|c|c|c|c|c|}
\hline \multirow[t]{2}{*}{ Concept } & \multicolumn{3}{|c|}{ Unit cost $(€, 2018)$} & \multirow[t]{2}{*}{ Source } \\
\hline & $\begin{array}{l}\text { Base } \\
\text { case }\end{array}$ & $\begin{array}{l}\text { Minimum } \\
\text { scenario }\end{array}$ & $\begin{array}{l}\text { Maximum } \\
\text { scenario }\end{array}$ & \\
\hline $\begin{array}{l}\text { Annual maintenance of } \\
\text { phototherapy equipment }\end{array}$ & 18.29 & 14.63 & 21.95 & 43 \\
\hline $\begin{array}{l}\text { Hospital pharmacy service } \\
\text { pharmacist, compounding } \\
\text { pharmaceutical (h) }\end{array}$ & 27.32 & 24.04 & 32.78 & 44 \\
\hline $\begin{array}{l}\text { Hospital pharmacy service } \\
\text { assistant, compounding } \\
\text { pharmaceutical (h) }\end{array}$ & 16.60 & 14.61 & 19.92 & 44 \\
\hline Ethanol $96(\mathrm{~mL})$ & 0.03 & 0.02 & 0.03 & 40 \\
\hline $\begin{array}{l}\text { Sterilized/White petroleum } \\
\text { jelly (g) }\end{array}$ & 0.10 & 0.04 & 0.29 & 40 \\
\hline $\begin{array}{l}\text { Vacuflasc }^{\circledR} 500 \mathrm{~mL} \text { sterile } \\
\text { flask (unit) }\end{array}$ & 5.51 & 4.41 & 6.61 & 45 \\
\hline Needles (unit) & 0.12 & 0.04 & 0.22 & 46 \\
\hline $\begin{array}{l}\text { Absorbent sterile cotton } \\
\text { gauze (unit) }\end{array}$ & 0.06 & 0.05 & 0.06 & 40 \\
\hline Gloves (unit) & 0.04 & 0.00 & 0.07 & 47 \\
\hline
\end{tabular}

Notes: a Considering equivalent usage distribution between atorvastatin $10 \mathrm{mg} /$ day and simvastatin $20 \mathrm{mg} /$ day. ${ }^{b}$ Includes the following assessment: aspartate aminotransferase, alanine amino transferase, gamma glutamyl transferase, alkaline phosphatase, bilirubin, albumin and prothrombin time. Includes the following assessments: thyroxine and thyrotropin ${ }^{\mathrm{d} C o n s i d e r i n g ~ t h e ~ p a r t i a l ~ a t t r i b u t i o n ~ m e t h o d . ~}$

Abbreviations: ANA, antinuclear antibodies; IFN $\alpha$, interferon alfa; IV, intravenous; MIU, million international units; OR, oral; PUVA, psoralens with ultraviolet A light; TSEB, total skin electron beam; CT, computerized axial tomography scan; TG, triglycerides; TP, topical; NB-UVB, narrowband ultraviolet B light.

processes of various topical carmustine-compounded preparations were taken into account. Their usage distribution, their mean daily dose and time until achieving complete response (CR) were also included. Laboratory tests and follow-up visits were also considered ( $\underline{\text { Table S1 }}) .{ }^{44,51-55}$

\section{Phototherapies (PUVA and NB-UVB)}

The weekly frequency and number of phototherapy sessions, together with the mean duration until achieving CR were considered for PUVA and NB-UVB. Laboratory tests and follow-up visits were taken into account. For PUVAbased phototherapy, it was agreed that for the base case, no patient would receive maintenance treatment with PUVA after achieving CR (Table S2).${ }^{56-61}$

\section{Total skin electron beam therapy}

The usage distribution, treatment duration and number of sessions until achieving CR of various TSEBT schedules were taken into consideration. Laboratory tests and followup visits were also taken into account (Table S3). ${ }^{62-67}$ 


\section{Topical corticosteroids}

The distribution of topical corticosteroids authorized and commercialized in Spain, the amount of product required for topical application and the laboratory tests and followup visits were taken into account. ${ }^{40,68-70}$ It was estimated that the amount of cream or gel that fits on the tip of a finger $(0.5 \mathrm{~g})$ would be enough to treat the surface of both of the patient's hands, equivalent to $2 \%$ of body surface area $(\underline{\text { Table S4}}) .^{71}$

\section{Systemic treatments alone or in combination with SDT \\ Systemic retinoids}

The usage distribution and dose of systemic retinoids authorized and commercialized in Spain were considered. Additionally, the median duration of treatments, the use of concomitant treatments, together with the laboratory tests and follow-up visits were taken into account (Table S5) ${ }^{70,72-75}$

\section{Systemic retinoids in combination with PUVA phototherapy}

The weekly frequency, number of sessions and mean duration until achieving CR of PUVA phototherapy (in combination with systemic retinoids) were considered. In addition, the usage distribution and dose of systemic retinoids authorized and commercialized in Spain, while been used in combination with PUVA phototherapy to treat MF-CTCL, were taken into account. Concomitant treatments, laboratory tests and followup visits were also considered (Table S6) ${ }^{76}$

\section{IFN $\alpha$ in combination with PUVA phototherapy}

The mean duration until achieving $\mathrm{CR}$, together with the IFN $\alpha$ dose from authorized and commercialized presentations in Spain were taken into account. The clinical evidence identified from medical literature would not allow us to determine the number of PUVA sessions (in combination with IFN $\alpha$ ) needed to achieve the CR. ${ }^{77-79}$ Thus, it was conservatively assumed that the weekly frequency of PUVA sessions in combination with IFN $\alpha$ would be equivalent to PUVA in monotherapy. PUVA exposure was not considered until patients had reached the end of the third week of IFN $\alpha$ treatment. Laboratory tests and follow-up visits were also taken into consideration (Table S7). ${ }^{77}$

\section{Sensitivity analysis}

In order to highlight the difficulties to achieve consensus regarding whether or not to include a maintenance regimen in PUVA-based phototherapy treatment, a sensitivity analysis scenario taking into account that a reduced percentage $(10 \%)$ of MF patients in the Spanish setting would continue to receive PUVA maintenance therapy after achieving CR has been carried out.

Likewise, it was suggested that a multivariate extreme sensitivity analysis should be carried out in order to estimate treatment costs from scenarios that took into account the extreme parameters (unit cost and use of resources): the most optimistic case possible (minimum scenario) compared with the most pessimistic case possible (maximum scenario). For the healthcare use of resources, the range of variation obtained by the expert panel was taken into account. For costs, the extreme values (minimum and maximum) of the source used, or where this was not available, a variation of $\pm 20 \%$ of the base case cost, were considered.

\section{Results}

The base case results obtained for time horizons at 1,3 and 6 months, respectively, are presented below. For each time horizon, the results obtained for minimum and maximum scenarios based on the multivariate extreme sensitivity analysis are shown in brackets.

\section{Skin-directed treatments Topical carmustine}

The treatment cost for carmustine-based topical chemotherapy was $€ 6,593.36 \quad(€ 2,411.12-€ 10,814.51), \quad € 19,780.09$ $(€ 2,411.12-€ 32,443.54)$ and $€ 27,592.78 \quad(€ 2,411.12-$ $€ 64,887.08)$ for time horizons of 1,3 and 6 months, respectively. Pharmaceutical costs were the main component of treatment cost $(\geq 99.79 \%$ of the total cost, in all cases) (Table 2).

\section{Phototherapies (PUVA and NB-UVB)}

As a base case, the treatment cost for PUVA treatment was $€ 1,098.68$ (€538.10-€2,328.99), €2,999.99 (€1,453.29$€ 6,294.46)$ and $€ 3,187.60(€ 1,453.29-€ 8,559.67)$ for time horizons of 1, 3 and 6 months, respectively. The cost of phototherapy sessions represented the main component of treatment cost (between $85.05 \%$ and $95.87 \%$ of the total cost, depending on the case) (Table 2).

As an alternative scenario, if $10 \%$ of MF patients continued receiving PUVA maintenance treatment after reaching CR, PUVA treatment cost would be $€ 1,098.68$, $€ 2,999.99$ and $€ 3,294.00$ for time horizons 1,3 and 6 months, respectively. Time horizons at 1 and 3 months (4.35 and 13.04 weeks, respectively) were not enough to exceed the mean duration until achieving CR (13.89 weeks). 
Therefore, alternative scenario results showed a slight difference to the base case $(3.34 \%$ increase $)$ only for the 6-month time horizon.

As shown in Table 2, the treatment cost for NB-UVB treatment was $€ 1,657.47$ (€651.13-€2,217.01), €4,842.10 $(€ 1,296.46-€ 6,594.27)$ and $€ 4,842.10$ (€1,296.46-€8,782.89) for time horizons of 1,3 and 6 months, respectively. Phototherapy sessions costs were the main component of treatment cost ( $\geq 97.05 \%$ of the total cost, in all cases).

\section{Total skin electron beam therapy}

The cost of TSEBT was $€ 6,796.45$ (€4,415.84-€9,454.26) considering 1-month time horizon, and $€ 7,913.34$ $(€ 5,237.05-€ 10,923.46)$ when considering 3 and 6 months time horizons. TSEBT sessions costs represented the main component of the treatment cost (between $86.43 \%$ and $97.84 \%$ of the total cost, depending on the case) (Table 2).

\section{Topical corticosteroids}

Cost of topical corticosteroids was $€ 17.16$ (€4.83-€78.09), $€ 51.49$ (€14.50-€234.26) and €102.97 (€28.99-€468.53) for time horizons of 1,3 and 6 months, respectively. Pharmaceutical costs represented the main cost component (between $92.94 \%$ and $98.24 \%$ of the total cost, depending on the case) (Table 2).

\section{Systemic treatments alone or in combination with SDT Systemic retinoids}

The cost of treatment with systemic retinoids was $€ 2,026.03$ (€479.40-€4,172.65), €5,206.63 (€479.40-€10,120.12) and $€ 7,426.42$ (€479.40-€19,041.32) for time horizons of 1,3 and 6 months, respectively. Pharmaceutical costs were the main component of the treatment cost (between $63.75 \%$ and $88.50 \%$ of the total cost, depending on the case) (Table 3 ).

\section{Systemic retinoids in combination with PUVA phototherapy}

The cost of combined treatment based on PUVA phototherapy together with systemic retinoids was $€ 3,066.50$ (€1,698.48-€5,260.62), €8,271.26 (€4,860.29-€13,316.38) and $€ 10,046.58$ (€5,938.77-€16,064.16) for time horizons of 1,3 and 6 months, respectively. Pharmaceutical costs attributed to systemic retinoids together with phototherapy sessions costs represented the main component of the treatment cost (between $70.57 \%$ and $96.83 \%$ of the total cost, depending on the case) (Table 3 ).

\section{IFN $\alpha$ in combination with PUVA phototherapy}

The cost of combined treatment based on PUVA phototherapy together with IFN $\alpha$ was $€ 1,541.09$ (€1,009.75-€2,756.10), $€ 5,167.57$ (€3,361.65-€9,742.06) and €6,404.55 (€4,163.87$€ 12,124.95)$ for time horizons of 1,3 and 6 months, respectively. Pharmaceutical and administration costs attributed to IFN $\alpha$ together with phototherapy sessions costs were the main component of the treatment cost (between $84.20 \%$ and $97.78 \%$ of the total cost, depending on the case) (Table 3 ).

\section{Discussion}

As shown in Figure 2, topical corticosteroids followed by PUVA and NB-UVB phototherapies were, regardless of the established time horizon, the treatments with the lowest associated direct healthcare costs. In contrast, when considering 1-month time horizon, the treatment with the highest direct healthcare cost was TSEBT, a rescue treatment used in early-stage MF patients in the Spanish setting. When considering time horizons for 3 and 6 months, the treatment with the highest direct healthcare costs was carmustine-based topical chemotherapy. In summary, topical corticosteroids and phototherapies remain among the treatments with the least direct healthcare costs associated with the management of early-stage MF patients. In contrast, systemic retinoids, PUVA in combination with systemic retinoids or IFN $\alpha$, TSEBT and particularly, topical carmustine-based chemotherapy are among the treatments with the highest direct healthcare costs.

For topical application treatments, when pharmaceutical costs were divided by their respective time horizon, the results remained equal. Consequently, pharmaceutical costs of topical treatments present a time-proportional cost. For the remaining treatments, costs were allocated based on the number of phototherapy or radiotherapy sessions, or the time until achieving $\mathrm{CR}$, which justifies that certain costs remain equivalent over various time horizons. For example, in the case of phototherapies, costs were allocated based on the mean duration until achieving CR (13.89 weeks [12.64 weeks-18.00 weeks] and 12.81 weeks [8.77 weeks-17.38 weeks] for PUVA and NB-UVB, respectively). For this reason, for the minimum scenario, both phototherapies presented the same cost at 3 and 6 months. However, this equivalence was only maintained for NB-UVB phototherapy in the base case results. The time horizons adopted in the present analysis were established according to the most common follow-up timeframes, treatment durations and time until complete 
Table 2 Estimated costs for skin-directed treatments

\begin{tabular}{|c|c|c|c|c|c|c|}
\hline & \multicolumn{2}{|c|}{ Base case } & \multicolumn{2}{|c|}{ Minimum scenario } & \multicolumn{2}{|c|}{ Maximum scenario } \\
\hline & $€, 2018$ & $\%$ & $€, 2018$ & $\%$ & $€, 2018$ & $\%$ \\
\hline \multicolumn{7}{|l|}{ Topical carmustine } \\
\hline \multicolumn{7}{|l|}{ Time horizon: I month } \\
\hline Pharmaceutical costs & $6,582.28$ & $99.83 \%$ & $2,408.77$ & $99.90 \%$ & $|0,79| .7 \mid$ & $99.79 \%$ \\
\hline Lab tests and follow-up visits costs & 11.09 & $0.17 \%$ & 2.34 & $0.10 \%$ & 22.80 & $0.21 \%$ \\
\hline Total cost & $6,593.36$ & $100.00 \%$ & $2,411.12$ & $100.00 \%$ & $|0,8| 4.5 \mid$ & $100.00 \%$ \\
\hline \multicolumn{7}{|l|}{ Time horizon: 3 months } \\
\hline Pharmaceutical costs & $19,746.83$ & $99.83 \%$ & $2,408.77$ & $99.90 \%$ & $32,375.13$ & $99.79 \%$ \\
\hline Lab tests and follow-up visits costs & 33.27 & $0.17 \%$ & 2.34 & $0.10 \%$ & 68.41 & $0.21 \%$ \\
\hline Total cost & $19,780.09$ & $100.00 \%$ & $2,411.12$ & $100.00 \%$ & $32,443.54$ & $100.00 \%$ \\
\hline \multicolumn{7}{|l|}{ Time horizon: 6 months } \\
\hline Pharmaceutical costs & $27,546.37$ & $99.83 \%$ & $2,408.77$ & $99.90 \%$ & $64,750.27$ & $99.79 \%$ \\
\hline Lab tests and follow-up visits costs & 46.41 & $0.17 \%$ & 2.34 & $0.10 \%$ & $136.8 \mid$ & $0.21 \%$ \\
\hline Total cost & $27,592.78$ & $100.00 \%$ & $2,411.12$ & $100.00 \%$ & $64,887.08$ & $100.00 \%$ \\
\hline \multicolumn{7}{|l|}{ PUVA phototherapy } \\
\hline \multicolumn{7}{|l|}{ Time horizon: I month } \\
\hline Phototherapy sessions costs & 949.13 & $86.39 \%$ & 477.98 & $88.83 \%$ & ।,980.91 & $85.05 \%$ \\
\hline Lab tests and follow-up visits costs & 148.03 & $13.47 \%$ & 58.90 & $10.95 \%$ & 346.25 & $14.87 \%$ \\
\hline Associated maintenance costs & 1.52 & $0.14 \%$ & 1.22 & $0.23 \%$ & 1.83 & $0.08 \%$ \\
\hline Total cost & $1,098.68$ & $100.00 \%$ & 538.10 & $100.00 \%$ & $2,328.99$ & $100.00 \%$ \\
\hline \multicolumn{7}{|l|}{ Time horizon: 3 months } \\
\hline Phototherapy sessions costs & $2,847.39$ & $94.91 \%$ & $1,390.84$ & $95.70 \%$ & $5,942.72$ & $94.41 \%$ \\
\hline Lab tests and follow-up visits costs & 148.03 & $4.93 \%$ & 58.90 & $4.05 \%$ & 346.25 & $5.50 \%$ \\
\hline Associated maintenance costs & 4.57 & $0.15 \%$ & 3.55 & $0.24 \%$ & 5.49 & $0.09 \%$ \\
\hline Total cost & 2,999.99 & $100.00 \%$ & $1,453.29$ & $100.00 \%$ & $6,294.46$ & $100.00 \%$ \\
\hline \multicolumn{7}{|l|}{ Time horizon: 6 months } \\
\hline Phototherapy sessions costs & $3,034.70$ & $95.20 \%$ & $1,390.84$ & $95.70 \%$ & $8,205.84$ & $95.87 \%$ \\
\hline Lab tests and follow-up visits costs & 148.03 & $4.64 \%$ & 58.90 & $4.05 \%$ & 346.25 & $4.05 \%$ \\
\hline Associated maintenance costs & 4.87 & $0.15 \%$ & 3.55 & $0.24 \%$ & 7.58 & $0.09 \%$ \\
\hline Total cost & $3,187.60$ & $100.00 \%$ & ।,453.29 & $100.00 \%$ & $8,559.67$ & $100.00 \%$ \\
\hline \multicolumn{7}{|l|}{ NB-UVB phototherapy } \\
\hline \multicolumn{7}{|l|}{ Time horizon: I month } \\
\hline Phototherapy sessions costs & $1,632.51$ & $98.49 \%$ & 631.91 & $97.05 \%$ & $2,186.80$ & $98.64 \%$ \\
\hline Lab tests and follow-up visits costs & 23.43 & $1.41 \%$ & 18.00 & $2.76 \%$ & 28.38 & $1.28 \%$ \\
\hline Associated maintenance costs & 1.52 & $0.09 \%$ & 1.22 & $0.19 \%$ & 1.83 & $0.08 \%$ \\
\hline Total cost & $1,657.47$ & $100.00 \%$ & 651.13 & $100.00 \%$ & $2,217.01$ & $100.00 \%$ \\
\hline \multicolumn{7}{|l|}{ Time horizon: 3 months } \\
\hline Phototherapy sessions costs & $4,8 \mid 4.17$ & $99.42 \%$ & $1,276.00$ & $98.42 \%$ & $6,560.40$ & $99.49 \%$ \\
\hline Lab tests and follow-up visits costs & 23.43 & $0.48 \%$ & 18.00 & $1.39 \%$ & 28.38 & $0.43 \%$ \\
\hline Associated maintenance costs & 4.49 & $0.09 \%$ & 2.46 & $0.19 \%$ & 5.49 & $0.08 \%$ \\
\hline Total cost & $4,842.10$ & $100.00 \%$ & $1,296.46$ & $100.00 \%$ & $6,594.27$ & $100.00 \%$ \\
\hline \multicolumn{7}{|l|}{ Time horizon: 6 months } \\
\hline Phototherapy sessions costs & $4,8 \mid 4.17$ & $99.42 \%$ & $1,276.00$ & $98.42 \%$ & $8,747.20$ & $99.59 \%$ \\
\hline Lab tests and follow-up visits costs & 23.43 & $0.48 \%$ & 18.00 & $1.39 \%$ & 28.38 & $0.32 \%$ \\
\hline Associated maintenance costs & 4.49 & $0.09 \%$ & 2.46 & $0.19 \%$ & 7.32 & $0.08 \%$ \\
\hline Total cost & $4,842.10$ & $100.00 \%$ & $1,296.46$ & $100.00 \%$ & $8,782.89$ & $100.00 \%$ \\
\hline
\end{tabular}

(Continued) 
Table 2 (Continued).

\begin{tabular}{|c|c|c|c|c|c|c|}
\hline & \multicolumn{2}{|c|}{ Base case } & \multicolumn{2}{|c|}{ Minimum scenario } & \multicolumn{2}{|c|}{ Maximum scenario } \\
\hline \multicolumn{7}{|l|}{ TSEBT } \\
\hline $\begin{array}{l}\text { Time horizon: I month } \\
\text { Radiotherapy sessions costs } \\
\text { Lab tests and follow-up visits costs } \\
\text { Total cost }\end{array}$ & $\begin{array}{l}6,279.56 \\
516.89 \\
6,796.45\end{array}$ & $\begin{array}{l}92.39 \% \\
7.61 \% \\
100.00 \%\end{array}$ & $\begin{array}{l}4,303.19 \\
112.66 \\
4,415.84\end{array}$ & $\begin{array}{l}97.45 \% \\
2.55 \% \\
100.00 \%\end{array}$ & $\begin{array}{l}8,171.01 \\
1,283.25 \\
9,454.26\end{array}$ & $\begin{array}{l}86.43 \% \\
13.57 \% \\
100.00 \%\end{array}$ \\
\hline $\begin{array}{l}\text { Time horizon: } 3 \text { months } \\
\text { Radiotherapy sessions costs } \\
\text { Lab tests and follow-up visits costs } \\
\text { Total cost }\end{array}$ & $\begin{array}{l}7,395.28 \\
518.06 \\
7,913.34\end{array}$ & $\begin{array}{l}93.45 \% \\
6.55 \% \\
100.00 \%\end{array}$ & $\begin{array}{l}5,124.05 \\
113.00 \\
5,237.05\end{array}$ & $\begin{array}{l}97.84 \% \\
2.16 \% \\
100.00 \%\end{array}$ & $\begin{array}{l}9,638.17 \\
1,285.28 \\
10,923.46\end{array}$ & $\begin{array}{l}88.23 \% \\
11.77 \% \\
100.00 \%\end{array}$ \\
\hline $\begin{array}{l}\text { Time horizon: } 6 \text { months } \\
\text { Radiotherapy sessions costs } \\
\text { Lab tests and follow-up visits costs } \\
\text { Total cost }\end{array}$ & $\begin{array}{l}7,395.28 \\
518.06 \\
7,913.34\end{array}$ & $\begin{array}{l}93.45 \% \\
6.55 \% \\
100.00 \%\end{array}$ & $\begin{array}{l}5,124.05 \\
113.00 \\
5,237.05\end{array}$ & $\begin{array}{l}97.84 \% \\
2.16 \% \\
100.00 \%\end{array}$ & $\begin{array}{l}9,638.17 \\
1,285.28 \\
10,923.46\end{array}$ & $\begin{array}{l}88.23 \% \\
11.77 \% \\
100.00 \%\end{array}$ \\
\hline Topical corticosteroids & & & & & & \\
\hline $\begin{array}{l}\text { Time horizon: I month } \\
\text { Pharmaceutical costs } \\
\text { Lab tests and follow-up visits costs } \\
\text { Total cost }\end{array}$ & $\begin{array}{l}16.33 \\
0.83 \\
17.16\end{array}$ & $\begin{array}{l}95.16 \% \\
4.84 \% \\
100.00 \%\end{array}$ & $\begin{array}{l}4.49 \\
0.34 \\
4.83\end{array}$ & $\begin{array}{l}92.94 \% \\
7.06 \% \\
100.00 \%\end{array}$ & $\begin{array}{l}76.71 \\
1.37 \\
78.09\end{array}$ & $\begin{array}{l}98.24 \% \\
1.76 \% \\
100.00 \%\end{array}$ \\
\hline $\begin{array}{l}\text { Time horizon: } 3 \text { months } \\
\text { Pharmaceutical costs } \\
\text { Lab tests and follow-up visits costs } \\
\text { Total cost }\end{array}$ & $\begin{array}{l}49.00 \\
2.49 \\
51.49\end{array}$ & $\begin{array}{l}95.16 \% \\
4.84 \% \\
100.00 \%\end{array}$ & $\begin{array}{l}13.47 \\
1.02 \\
14.50\end{array}$ & $\begin{array}{l}92.94 \% \\
7.06 \% \\
100.00 \%\end{array}$ & $\begin{array}{l}230.14 \\
4.12 \\
234.26\end{array}$ & $\begin{array}{l}98.24 \% \\
1.76 \% \\
100.00 \%\end{array}$ \\
\hline
\end{tabular}

Abbreviations: PUVA, psoralens with ultraviolet A light; NB-UVB, narrowband ultraviolet B light; TSEBT, total skin electron beam therapy.

response of the treatments assessed. Adopting one-year time horizon would not be appropriate for this analysis, as during one-year timeframe different MF-CTCL treatments could be used in combination or alternately. To establish one-year therapeutic pattern common for all MFCTCL patients in Spain would be practically unfeasible due to the highly individualized therapeutic approach of this rare disease in the Spanish clinical setting. Therefore, considering horizons of 1,3 and 6 months would be the best approach to capture and reflect healthcare resource usage within MF-CTCL patients being managed in the Spanish setting. The authors encourage the development of future studies to provide data regarding the time to progression or initiation of subsequent MF-CTCL treatments, especially among early-stage patients. This could enhance the development of further economic studies.
The results of this analysis are always shown together with their respective extreme scenarios. These scenarios, although unlikely to occur, are intended to estimate borderline situations that may arise when considering the extreme ranges for all parameters and assumptions taken into account. The application of extreme sensitivity scenarios allows us to assess the uncertainty associated with these parameters and assumptions. The results from these sensitivity scenarios must be considered with caution, particularly avoiding cross-comparisons. Despite this, in general terms, the results observed in the extreme scenarios are consistent with the conclusions from the base case, namely that topical corticosteroids and both phototherapies remain among the lowest direct healthcare cost associated with early-stage MF treatment. In contrast, TSEBT and topical carmustine-based chemotherapy remain among the 
Table 3 Estimated costs for systemic treatments alone or in combination with skin-directed treatments

\begin{tabular}{|c|c|c|c|c|c|c|}
\hline & \multicolumn{2}{|c|}{ Base case } & \multicolumn{2}{|c|}{ Minimum scenario } & \multicolumn{2}{|c|}{ Maximum scenario } \\
\hline & $€, 2018$ & $\%$ & $€, 2018$ & $\%$ & $€, 2018$ & $\%$ \\
\hline \multicolumn{7}{|l|}{ Systemic retinoids } \\
\hline \multicolumn{7}{|l|}{ Time horizon: I month } \\
\hline Pharmaceutical costs & $1,495.16$ & $73.80 \%$ & 367.28 & $76.61 \%$ & $2,660.22$ & $63.75 \%$ \\
\hline Lab tests and follow-up visits costs & 530.87 & $26.20 \%$ & 112.13 & $23.39 \%$ & $\mathrm{I}, 5 \mathrm{I} 2.43$ & $36.25 \%$ \\
\hline Total cost & $2,026.03$ & $100.00 \%$ & 479.40 & $100.00 \%$ & $4,172.65$ & $100.00 \%$ \\
\hline \multicolumn{7}{|l|}{ Time horizon: 3 months } \\
\hline Pharmaceutical costs & $4,485.47$ & $86.15 \%$ & 367.28 & $76.61 \%$ & $7,980.66$ & $78.86 \%$ \\
\hline Lab tests and follow-up visits costs & 721.16 & $13.85 \%$ & 112.13 & $23.39 \%$ & $2,139.45$ & $21.14 \%$ \\
\hline Total cost & $5,206.63$ & $100.00 \%$ & 479.40 & $100.00 \%$ & $10,120.12$ & $100.00 \%$ \\
\hline \multicolumn{7}{|l|}{ Time horizon: 6 months } \\
\hline Pharmaceutical costs & $6,572.46$ & $88.50 \%$ & 367.28 & $76.61 \%$ & $15,961.33$ & $83.82 \%$ \\
\hline Lab tests and follow-up visits costs & 853.96 & $11.50 \%$ & 112.13 & $23.39 \%$ & $3,079.99$ & $16.18 \%$ \\
\hline Total cost & $7,426.42$ & $100.00 \%$ & 479.40 & $100.00 \%$ & $19,041.32$ & $100.00 \%$ \\
\hline \multicolumn{7}{|c|}{ Systemic retinoids in combination with PUVA phototherapy } \\
\hline \multicolumn{7}{|l|}{ Time horizon: I month } \\
\hline Pharmaceutical costs (retinoids, OR) & $1,983.69$ & $64.69 \%$ & I,442.15 & $84.91 \%$ & $2,474.47$ & $47.04 \%$ \\
\hline Phototherapy sessions costs & 522.02 & $17.02 \%$ & 119.49 & $7.04 \%$ & $\mathrm{I}, 238.07$ & $23.53 \%$ \\
\hline Lab tests and follow-up visits costs & 559.27 & $18.24 \%$ & 135.62 & $7.98 \%$ & $\mathrm{I}, 546.25$ & $29.39 \%$ \\
\hline Associated maintenance costs & 1.52 & $0.05 \%$ & 1.22 & $0.07 \%$ & 1.83 & $0.03 \%$ \\
\hline Total cost & $3,066.50$ & $100.00 \%$ & $1,698.48$ & $100.00 \%$ & $5,260.62$ & $100.00 \%$ \\
\hline \multicolumn{7}{|l|}{ Time horizon: 3 months } \\
\hline Pharmaceutical costs (retinoids, OR) & $5,951.06$ & $71.95 \%$ & $4,326.45$ & $89.02 \%$ & $7,423.41$ & $55.75 \%$ \\
\hline Phototherapy sessions costs & I,566.07 & $18.93 \%$ & 358.48 & $7.38 \%$ & $3,7 \mid 4.20$ & $27.89 \%$ \\
\hline Lab tests and follow-up visits costs & 749.56 & $9.06 \%$ & 171.70 & $3.53 \%$ & $2,173.28$ & $16.32 \%$ \\
\hline Associated maintenance costs & 4.57 & $0.06 \%$ & 3.66 & $0.08 \%$ & 5.49 & $0.04 \%$ \\
\hline Total cost & $8,271.26$ & $100.00 \%$ & $4,860.29$ & $100.00 \%$ & $13,316.38$ & $100.00 \%$ \\
\hline \multicolumn{7}{|l|}{ Time horizon: 6 months } \\
\hline Pharmaceutical costs (retinoids, OR) & $7,304.31$ & $72.70 \%$ & $5,310.27$ & $89.42 \%$ & $9,111.47$ & $56.72 \%$ \\
\hline Phototherapy sessions costs & $1,922.18$ & $19.13 \%$ & 440.00 & $7.41 \%$ & $4,558.80$ & $28.38 \%$ \\
\hline Lab tests and follow-up visits costs & 814.47 & $8.11 \%$ & 184.01 & $3.10 \%$ & $2,387.15$ & $14.86 \%$ \\
\hline Associated maintenance costs & 5.61 & $0.06 \%$ & 4.49 & $0.08 \%$ & 6.73 & $0.04 \%$ \\
\hline Total cost & $10,046.58$ & $100.00 \%$ & $5,938.77$ & $100.00 \%$ & $16,064.16$ & $100.00 \%$ \\
\hline \multicolumn{7}{|c|}{ IFN $\alpha$ in combination with PUVA phototherapy } \\
\hline \multicolumn{7}{|l|}{ Time horizon: I month } \\
\hline Pharmaceutical costs (IFN $\alpha$ ) & 429.21 & $27.85 \%$ & 413.55 & $40.96 \%$ & 704.92 & $25.58 \%$ \\
\hline Administration costs (IFN $\alpha$ ) & 397.72 & $25.81 \%$ & 248.85 & $24.65 \%$ & 546.59 & $19.83 \%$ \\
\hline Phototherapy sessions costs & 512.27 & $33.24 \%$ & 257.98 & $25.55 \%$ & $1,069.15$ & $38.79 \%$ \\
\hline Lab tests and follow-up visits costs & 200.37 & $13.00 \%$ & 88.15 & $8.73 \%$ & 433.61 & $15.73 \%$ \\
\hline Associated maintenance costs & 1.52 & $0.10 \%$ & 1.22 & $0.12 \%$ & 1.83 & $0.07 \%$ \\
\hline Total cost & $1,541.09$ & $100.00 \%$ & $1,009.75$ & $100.00 \%$ & $2,756.10$ & $100.00 \%$ \\
\hline \multicolumn{7}{|l|}{ Time horizon: 3 months } \\
\hline Pharmaceutical costs (IFN $\alpha$ ) & $1,358.94$ & $26.30 \%$ & $1,309.36$ & $38.95 \%$ & $2,632.24$ & $27.02 \%$ \\
\hline Administration costs (IFN $\alpha$ ) & $1,193.16$ & $23.09 \%$ & 746.56 & $22.21 \%$ & $\mathrm{I}, 639.76$ & $16.83 \%$ \\
\hline Phototherapy sessions costs & $2,410.53$ & $46.65 \%$ & $1,213.93$ & $36.11 \%$ & $5,030.96$ & $51.64 \%$ \\
\hline Lab tests and follow-up visits costs & 200.37 & $3.88 \%$ & 88.15 & $2.62 \%$ & 433.61 & $4.45 \%$ \\
\hline
\end{tabular}

(Continued) 
Table 3 (Continued).

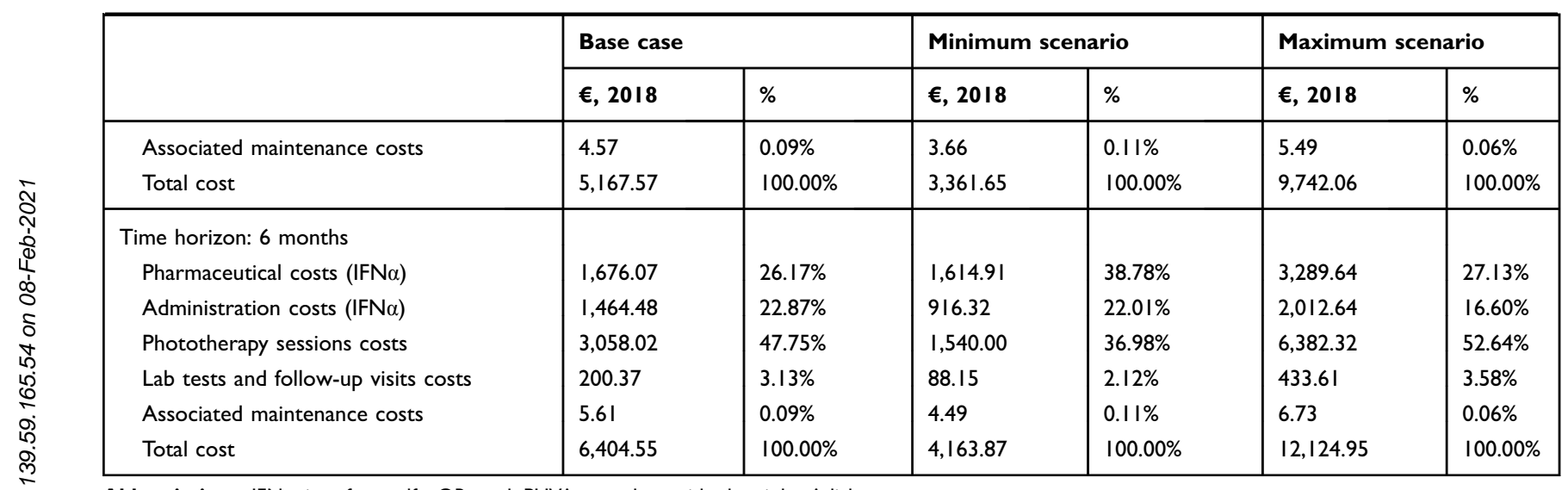

Abbreviations: IFN $\alpha$, interferon alfa; OR, oral; PUVA, psoralens with ultraviolet A light.

treatments with the highest direct healthcare costs. The sensitivity scenarios pointed out a high sensitivity of the results obtained in the present study to those parameters related to application patterns, treatment duration and time to achieve complete response.

The results of this analysis have shown that the most commonly used treatments in Spanish clinical practice during the early stages of MF represent a considerable direct healthcare cost. To our knowledge, this study is the first financial analysis carried out with the aim of identifying the therapeutic alternatives most commonly used in Spain for managing the early stages of MF, to determine their healthcare resources use and quantify their associated costs. The lack of national studies with similar objectives has prevented us from creating comparative arguments. However, the conclusions observed in this study are in line with previous publications carried out in other healthcare environments, ${ }^{35-37}$ which evidence that MF patients, even in the early stages, require considerable use of healthcare resources due to the high frequency of visits to outpatient care centers and pharmacy departments.

Given the low incidence of this rare disease, limited literature has been found regarding its management in the Spanish setting or regarding the use of healthcare resources. Despite the inherent nature and limitations of any consultative methodology using a reference expert panel, the participation and involvement of the Spanish clinical experts involved in this study have become an essential factor in achieving the proposed objectives. One of the limitations of the present study is the lack of a recommended daily dose defined by WHO Collaborative Centre for Drugs Statistics Methodology for topical treatments. This has forced us to apply certain assumptions during the estimation of topical corticosteroid

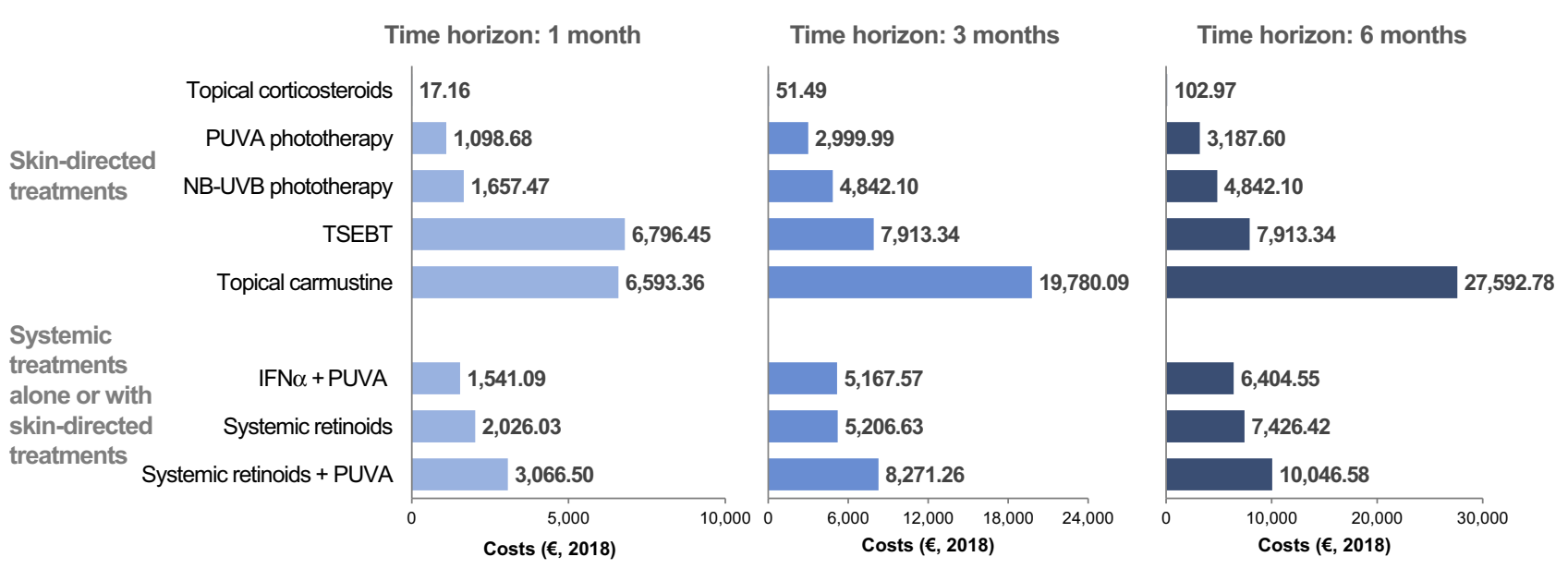

Figure 2 Cost of the main alternative treatments in managing the early stages of MF in Spain.

Abbreviations: IFN $\alpha$, interferon alfa; PUVA, psoralens and ultraviolet A light; TSEBT, total skin electron beam therapy; NB-UVB, narrow-band ultraviolet B light. 
usage per application. Likewise, to estimate the cost of topical carmustine-based chemotherapy, it was necessary to consider the acquisition, management, compounding, control and dispensing processes of various topical carmustine preparations in Spain. Given the lack of specific publications on these pharmaceutical compounding procedures, it was considered that the human resources involved in these activities would be equivalent to those indicated by Berlana et al, ${ }^{44}$ a multicenter cost analysis carried out in the Spanish setting, which details the human and equipment resources involved in the preparation, management and compounding for medicinal formulations other than topical carmustine. Nevertheless, considering the price per vial of carmustine, the associated compounding activities represent a limited portion $(<5 \%)$ of the estimated total costs of topical carmustine-based chemotherapy. Not to consider the costs associated to the adverse events management represent a study limitation, especially due to differential safety profile of the treatments evaluated. Therefore, the estimated direct health costs here presented could be underestimated, especially for the systemic treatments and for the TSEBT. Additionally, the results of this analysis would be underestimated due to not including the indirect costs associated to these treatments, especially for the phototherapies and the TSEBT. This is particularly relevant for MF-CTCL patients, taking into account their disease impact in terms of productivity loss. ${ }^{38}$ The authors encourage the development of future studies to provide data regarding the societal impact associated to the available treatments for MF-CTCL, especially considering the slowly progressive and chronic features of the disease, together with the emotional and functional impact of the disease. ${ }^{9,33,34}$ Further studies should explore the potential impact in terms of productivity loss and health-related quality of life burden associated to the available treatments for the management of MF-CTCL.

Treatment alternatives identified in this study are congruent with clinical data and treatment information on MF patients reported by AEDV's primary cutaneous lymphomas patient registry, ${ }^{20}$ and also concur with the treatments recommended for early-stage MF management in the main clinical practice guidelines. ${ }^{11,30-32}$ Additionally, the therapeutic options assessed in this study are consistent with the first results shown by the AEDV's primary cutaneous lymphomas. The SDTs assessed in this analysis represent $90.8 \%$ (topical corticosteroids), $86.1 \%$ (phototherapies), $8.3 \%$ (TSEBT) and $6.0 \%$ (topical chemotherapies) of the treatments used for MF patients recorded by the AEDV. With regard to the systemic treatments assessed in this analysis, the use of systemic retinoids and IFN $\alpha$ was described by $6.9 \%$ and $12.1 \%$, respectively, of MF patients recorded by the AEDV ${ }^{20}$ This is aligned with the indications from the expert panel consulted during this study, in which the use of combined therapies including systemic treatments for patients with early-stage MF is usually suggested for those non-eligible patients or those with a poor response to SDTs.

Based on the clinical expert panel, topical corticosteroids constitute the basis of MF management, being offered through all stages, especially during the initial ones. However, when topical corticosteroids are used in combination with other treatments, they are not considered as treatments per se, and the combination is, in general, perceived as a "monotherapy treatment". Long-term use of topical steroid may lead to atrophy and development of striae. This risk increases with the potency of topical corticosteroid and may lead to systemic absorption. ${ }^{80}$ Despite that, topical corticosteroids are often used as a symptomatic relief for the skin manifestations caused by the disease or the concomitant therapies. Therefore, topical corticosteroids were taken in the present analysis into account due to their wide use in clinical practice, particularly among early-stages MF patients. The lack of a standardized dose for their topical application forced us to include additional considerations (eg, amount of product required for each topical application, baseline body surface area involvement and its evolution through time). Therefore, the interpretation of topical corticosteroids results should be interpreted with caution.

The lack of clear, agreed or homogeneous treatment algorithms together with the range of treatment options available means that treating MF-CTCL becomes a highly individualized process. This, together with the few comparative studies available, leads the decision-maker to choose a specific treatment based on the stage of the disease, the clinical criteria, patient characteristics, the safety profile, patient preferences and resources available in each healthcare center. For this reason, having financial studies available is essential in order to include opportunity cost and cost-benefit elements among the arguments for assessing these treatments. Consequently, and taking advantage of the recently generated evidence from the AEDV registry of primary cutaneous lymphomas patients, ${ }^{18,20}$ we would strongly encourage adding evidence related to healthcare resources use in prospective or retrospective studies already developed in our setting. This would not only allow us to corroborate the results of 
the current study, but also to promote the development of further pharmacoeconomic evidence regarding CTCLs.

\section{Conclusions}

Despite the available information regarding the clinical features and comorbidities of MF-CTCL, there are limited data on the treatment patterns, clinical burden and financial implications of this rare disease. Results of this analysis show that topical corticosteroids, despite being considered as an adjuvant option especially for patients with generalized skin lesions, and phototherapies remain the treatments with the lowest direct healthcare costs for managing early-stage MF patients. In contrast, systemic retinoids in monotherapy, PUVA in combination with systemic retinoids or IFN $\alpha$, TSEBT and particularly, topical carmustine-based chemotherapy are among the treatments with the highest direct healthcare costs. The results of this analysis show that the treatments mostly used in Spanish clinical practice during the early stages of MF represent considerable associated healthcare costs. This information may be of interest to all those healthcare professionals interested in quantifying the financial implications for healthcare systems resulting from MF treatments, to identify unmet medical needs, to encourage those treatments that offer the most benefits, expectations and quality-oflife for patients and to assess the degree of efficiency of healthcare systems. In this respect, in order to encourage an efficient healthcare resources distribution, regardless of the disease or clinical circumstances, it is essential to determine the cost of alternative treatments.

\section{Abbreviations}

AEDV, Spanish Academy for Dermatology and Venerology; EORTC, European Organization for Research and Treatment of Cancer; IFN $\alpha$, interferon alfa; ISCL, International Society for Cutaneous Lymphomas; CR, complete response; CTCL, cutaneous T-cell lymphomas; MF, mycosis fungoides; PUVA, psoralens with ultraviolet A light; SDT, skin-directed treatments; TSEBT, total skin electron beam therapy; NB-UVB, narrowband ultraviolet B light.

\section{Acknowledgment}

This manuscript includes information presented at the European Organisation for Research and Treatment of Cancer - Cutaneous Lymphoma Task Force annual meeting, September 2018, in St. Gallen, Switzerland and published as a congress abstract at the following site: https://www.ejcan cer.com/article/S0959-8049(18)31295-4/fulltext.

\section{Author contributions}

All authors contributed to data analysis, drafting or revising the article, gave final approval of the version to be published, and agree to be accountable for all aspects of the work.

\section{Disclosure}

PLOR, OS, MTE, RMIB, RFdM and FG are, respectively, employed by Hospital 12 de Octubre, Hospital Universitari de Bellvitge, Hospital Clínic, Hospital de Basurto, Hospital Universitario Nuestra Señora de Candelaria and Parc de Salut Mar-Hospital del Mar. NLM and APM are employees of Oblikue Consulting, an independent contract health economic organization which received consultancy fees from Actelion Pharmaceuticals España S.L. and Helsinn Healthcare SA to conduct this research. The funding body was not involved in the study design, collection and interpretation of data, or in the decision to publish. PLOR has reported consultancy, participation to advisory boards and research support from Actelion Pharmaceuticals, Kyowa Kirin International, Takeda, and 4SC. PLOR also reports personal fees from Actelion and Helsinn, during the conduct of the study; personal fees from 4SC, Takeda, Miragen, Innate Pharma, Kyowa, Ricordati Rare Diseases, non-financial support from Meda, and a patent with PLCG1, outside the submitted work. OS reports personal fees, non-financial support from Takeda, personal fees from Kiowa kirim and Actelion, outside the submitted work. FG, NLM and APM received fees related to this study from Actelion Pharmaceuticals España S.L. and Helsinn Healthcare SA, during the conduct of the study. The authors report no other conflicts of interest in this work.

\section{References}

1. Kim EJ, Hess S, Richardson SK, et al. Immunopathogenesis and therapy of cutaneous $\mathrm{T}$ cell lymphoma. J Clin Invest. 2005;115 (4):798-812. doi:10.1172/JCI24826

2. Jawed SI, Myskowski PL, Horwitz S, Moskowitz A, Querfeld C. Primary cutaneous T-cell lymphoma (mycosis fungoides and Sézary syndrome). $J$ Am Acad Dermatol. 2014;70(2):205.e1-205.e16. doi:10.1016/j.jaad.2013.07.049

3. Willemze R, Jaffe ES, Burg G, et al. WHO-EORTC classification for cutaneous lymphomas. Blood. 2005;105(10):3768-3785. doi:10.1182/ blood-2004-09-3502

4. Swerdlow SH, Campo E, Pileri SA, et al. The 2016 revision of the World Health Organization classification of lymphoid neoplasms. Blood. 2016;127(20):2375-2390. doi:10.1182/blood-2016-01-643569 
5. Willemze R, Cerroni L, Kempf W, et al. The 2018 update of the WHO-EORTC classification for primary cutaneous lymphomas. Blood. 2019;133(16):1703-1714. doi:10.1182/blood-2018-11-881 268

6. Olsen EA. Evaluation, diagnosis, and staging of cutaneous lymphoma. Dermatol Clin. 2015;33(4):643-654. doi:10.1016/j.det.2015.06.001

7. Wilcox RA. Cutaneous T-cell lymphoma: 2016 update on diagnosis, risk-stratification, and management. Am J Hematol. 2016;91 (1):151-165. doi:10.1002/ajh.24233

8. Demierre M-F, Gan S, Jones J, Miller DR. Significant impact of cutaneous T-cell lymphoma on patients' quality of life. Cancer. 2006;107(10):2504-2511. doi:10.1002/cncr.22252

9. Angelis A, Tordrup D, Kanavos P. Socio-economic burden of rare diseases: a systematic review of cost of illness evidence. Health Policy (New York). 2015;119(7):964-979. doi:10.1016/j.healthpol.2014.12.016

10. Willemze R. Cutaneous T-cell lymphoma: epidemiology, etiology, and classification. Leuk Lymphoma. 2003;44(Suppl 3):S49-S54. doi:10.1080/ 10428190310001623766

11. Trautinger F, Eder J, Assaf C, et al. European Organisation for Research and Treatment of Cancer consensus recommendations for the treatment of mycosis fungoides/Sézary syndrome - Update 2017. Eur J Cancer. 2017;77:57-74. doi:10.1016/j.ejca.2017.02.027

12. Orphanet. Classic mycosis fungoides. Available from: https://www. orpha.net/consor/cgi-bin/OC_Exp.php?Lng=EN\&Expert=2584. Accessed November 28, 2018

13. Genetic and Rare Diseases Information Center (GARD). Mycosis fungoides. Available from: https://rarediseases.info.nih.gov/diseases/ 3863/mycosis-fungoides. Accessed November 19, 2018.

14. Wilson LD, Hinds GA, Yu JB. Age, race, sex, stage, and incidence of cutaneous lymphoma. Clin Lymphoma Myeloma Leuk. 2012;12 (5):291-296. doi:10.1016/j.clm1.2012.06.010

15. Imam MH, Shenoy PJ, Flowers CR, Phillips A, Lechowicz MJ. Incidence and survival patterns of cutaneous T-cell lymphomas in the United States. Leuk Lymphoma. 2013;54(4):752-759. doi:10.3109/ 10428194.2012.729831

16. Bradford PT, Devesa SS, Anderson WF, Toro JR. Cutaneous lymphoma incidence patterns in the United States: a population-based study of 3884 cases. Blood. 2009;113(21):5064-5073. doi:10.1182/blood-2008-10184168

17. Smith A, Crouch S, Lax S, et al. Lymphoma incidence, survival and prevalence 2004-2014: sub-type analyses from the UK's Haematological Malignancy Research Network. $\mathrm{Br} J$ Cancer. 2015;112(9):1575-1584. doi:10.1038/bjc.2015.94

18. Estrach T, Servitje O, Ortiz-Romero PL. Registro de linfomas cutáneos primarios de la AEDV [AEDV primary cutaneous lymphoma registry]. Actas Dermosifiliogr. 2017;108(3):181-183. doi:10.1016/j.ad.2017.02.008

19. Quaglino P, Maule M, Prince HM, et al. Global patterns of care in advanced stage mycosis fungoides/Sezary syndrome: a multicenter retrospective follow-up study from the Cutaneous Lymphoma International Consortium. Ann Oncol. 2017;28(10):2517-2525. doi:10.1093/annonc/ $\mathrm{mdx} 352$

20. Penate $Y$, Servitje $O$, Machan $S$, et al. The first year of the AEVD primary cutaneous lymphoma registry. Actas Dermosifiliogr. 2018;109(7):610-616. doi:10.1016/j.ad.2018.03.006

21. Hwang ST, Janik JE, Jaffe ES, Wilson WH. Mycosis fungoides and Sézary syndrome. Lancet. 2008;371(9616):945-957. doi:10.1016/ S0140-6736(08)60420-1

22. Girardi M, Heald PW, Wilson LD. The pathogenesis of mycosis fungoides. $N$ Engl $J$ Med. 2004;350(19):1978-1988. doi:10.1056/ NEJMra032810

23. Kazakov D, Burg G, Kempf W. Clinicopathological spectrum of mycosis fungoides. $J$ Eur Acad Dermatol Venereol. 2004;18 (4):397-415. doi:10.1111/j.1468-3083.2004.00937.x
24. Olsen E, Vonderheid E, Pimpinelli N, et al. Revisions to the staging and classification of mycosis fungoides and Sézary syndrome: a proposal of the International Society for Cutaneous Lymphomas (ISCL) and the cutaneous lymphoma task force of the European Organization of Research and Treatment of Ca. Blood. 2007;110 (6):1713-1722. doi:10.1182/blood-2007-03-055749

25. Agar NS, Wedgeworth E, Crichton S, et al. Survival outcomes and prognostic factors in mycosis fungoides/sézary syndrome: validation of the revised International Society for Cutaneous Lymphomas/ European Organisation for research and treatment of cancer staging proposal. J Clin Oncol. 2010;28(31):4730-4739. doi:10.1200/ JCO.2009.27.7665

26. Quaglino P, Pimpinelli N, Berti E, et al. Time course, clinical pathways, and long-term hazards risk trends of disease progression in patients with classic mycosis fungoides: a multicenter, retrospective follow-up study from the Italian Group of Cutaneous Lymphomas. Cancer. 2012;118(23):5830-5839. doi:10.1002/ cncr.27627

27. Kim Y, Liu H, Mraz-Gernhard S, Varghese A, Hoppe R. Longterm outcome of 525 patients with mycosis fungoides and sézary syndrome: clinical prognostic factors and risk for disease progression. Arch Dermatol. 2003;139(7):857-866. doi:10.1001/ archderm.139.7.857

28. Scarisbrick JJ, Kim YH, Whittaker SJ, et al. Prognostic factors, prognostic indices and staging in mycosis fungoides and Sézary syndrome: where are we now? Br J Dermatol. 2014;170(6):1226-1236. doi:10.1111/bjd.12909

29. Van Doorn R, Van Haselen C, Van Voorst Vader P, et al. Mycosis fungoides: disease evolution and prognosis of 309 dutch patients. Arch Dermatol. 2000;136(4):504-510. doi:10.1001/archderm.136.4.504

30. Network National Comprehensive Cancer. Mycosis fungoides/sezary syndrome (guidelines Version 4.2018). 2018. Available from: https:// www.ncen.org/.

31. Willemze R, Hodak E, Zinzani P, Specht L, Ladetto $M$, Committee EG. Primary cutaneous lymphomas: ESMO clinical practice guidelines for diagnosis, treatment and follow-up. Ann Oncol. 2018;29(Supp14):iv30-iv40. doi:10.1093/annonc/mdy133

32. Wilcox RA. Cutaneous T-cell lymphoma: 2017 update on diagnosis, risk-stratification, and management. Am J Hematol. 2017;92 (10):1085-1102. doi:10.1002/ajh.24876

33. Demierre MF, Olsen EA, Williams CA, Arduino JM, McNaughton KS. An in-depth assessment of the impact of pruritus on health-related quality of life of patients with mycosis fungoides/ sézary syndrome. J Support Oncol. 2011;9(3):e13-e19. doi:10.1016/j. suponc.2011.02.001

34. Hodak E, Lessin S, Friedland R, et al. New insights into associated co-morbidities in patients with cutaneous T-cell lymphoma (mycosis fungoides). Acta Derm Venereol. 2013;93(4):451-455. doi:10.2340/ 00015555-1496

35. Gu T, Raspa S, Tsang Y, Drake W. The burden of illness of mycosis fungoides cutaneous T-cell lymphoma: a retrospective cohort study of a commercially insured population in the U.S. Value Heal. 2016;19 (7):A608. doi:10.1016/j.jval.2016.09.1508

36. Ricci E, Cortelazzo S, Krulichova I, Garattini L. Direct medical costs of mycosis fungoides in specialized Italian hospital departments. Haematologica. 2005;90(2):270-272.

37. Tsang Y, Gu T, Sharma G, Raspa S, Drake B, Tan H. Healthcare resource utilization, costs of care, and treatment of mycosis fungoides cutaneous T-cell lymphoma patterns in a large managed care population: a retrospective US claims-based analysis. $J$ Dermatolog Treat. 2018;29(8):747-753. doi:10.1080/09546634.2018.1466026

38. Cameron H, Yule S, Dawe RS, Ibbotson SH, Moseley H, Ferguson J. Review of an established UK home phototherapy service 1998-2011: improving access to a cost-effective treatment for chronic skin disease. Public Health. 2014;128(4):317-324. doi:10.1016/j.puhe.2014.01.011 
39. Ministerio de Sanidad Consumo y Bienestar Social. Listado de Medicamentos Afectados Por Las Deducciones Del Real DecretoLey 8/2010 Noviembre 2018 [Medicines List Affected by the Royal Decree-Law 8/2010 November Deduction]. Madrid; 2018. Available from: https://www.mscbs.gob.es/en/profesionales/farmacia/ notasInfor.htm.

40. Bot PLUS: Base de Datos de Información Sanitaria [Bot PLUS: health information database]. Available from: https://botplusweb.por talfarma.com/botplus.aspx. Published 2019. Accessed July 19, 2019.

41. Oblikue Consulting SL. Spanish Health Costs Database: eSalud. Barcelona: Oblikue Consulting SL; 2018. Available from http://obli kue.com/bddcostes. Accessed July 19, 2019.

42. Nolla JM, Martín E, Llamas P, et al. An estimate of the cost of administering intravenous biological agents in Spanish day hospitals. Ther Clin Risk Manag. 2017;13:325-334. doi:10.2147/TCRM.S112062

43. Alfageme Roldán F, Bermejo Hernando A, Calvo González JL, Marqués Sánchez P. Coste efectividad de diferentes tratamientos para la psoriasis [Cost effectiveness of treatments of psoriasis]. Rev Esp Salud Pública. 2016;90:e1-e7.

44. Berlana D, Sabin P, Gimeno-Ballester V, et al. Cost analysis of adult parenteral nutrition systems; three-compartment bag versus customized. Nutr Hosp. 2013;28(6):2135-2141. doi:10.3305/ nh.2013.28.6.6862

45. Comunidad de Madrid (Atención Primaria Área 11). Publicación en el portal de la contratación pública PA/TA/AB/11/08/SU/10, de la Comunidad de Madrid [Publication on the public procurement portal, Community of Madrid].

46. Comunidad de Madrid. Pliego de prescripciones técnicas. Concurso suministro C. SUM 212/10 Material sanitario (agujas y jeringas). 2010 [Technical specifications document. Supply contract C. SUM 212/10 sanitary material (needles and syringes). 2010].

47. Gobierno de Aragón (Servicio Aragonés de Salud). Pliego-tipo cláusulas administrativas. Concursos de bienes con destino a centros dependientes del Servicio Aragonés de Salud. 2006 [Specification-type administrative clauses. Tenders destined to centers of the Aragon Health Service. 2006].

48. National Statistics Institute. National Health Survey: 2017. Madrid: National Statistics Institute; 2017.

49. Heald P, Mehlmauer M, Martin AG, et al. Topical bexarotene therapy for patients with refractory or persistent early-stage cutaneous T-cell lymphoma: results of the Phase III clinical trial. J Am Acad Dermatol. 2003;49(5):801-815. doi:10.1016/S0190-9622(03)01475-0

50. Committee for Medicinal Products for Human Use. European Public Assessment Report: LEDAGA (EMA/CHMP/13156/2017). Amsterdam; 2017.

51. Dávila C, Clérigues MN. Farmacotecnia: boletín informativo [Pharmacotechnics: newsletter]. Farmacotecnia. 2012;2(3):1-13. Available from: https://www.sefh.es/sefhpublicaciones/boletines-farm acotecnia/boletin-septiembre-diciembre-2012.pdf Published 2012. Accessed November 28, 2018.

52. Grupo de trabajo de Farmacotecnia de la Sociedad Española de Farmacia Hospitalaria. Información Lista Sociedad Española de Farmacia Hospitalaria. 2018. [Information list of the Spanish Society of Hospital Pharmacy. 2018].

53. Hospital Universitario 12 de Octubre (Servicio de Farmacia). Preparación de Medicamentos: Formulación Magistral. Volumen I [Drug Preparation: Master Formulation. Volume I]. Madrid: Hospital Universitario 12 de Octubre; 2010.

54. Zackheim HS, Epstein EH, Crain WR. Topical carmustine (BCNU) for cutaneous T cell lymphoma: a 15-year experience in 143 patients. $J$ Am Acad Dermatol. 1990;22(5):802-810. doi:10.1016/0190-9622(90)70112-U

55. British Columbia Cancer Drug Manual. Carmustine Monograph. Vancouver: Provincial Health Services Authority (PHSA); 2018. Available from: http://www.bccancer.bc.ca/health-professionals/clini cal-resources/cancer-drug-manual/drug-index\#c-content. Published 2018. Accessed November 28, 2018.
56. Hernández Z, Peñate Y, Hernández-Machín B, et al. Treatment of stage Ia and Ib mycosis fungoides with psoralen UVA monotherapy: an observational study in tertiary hospitals in the Canary Islands. Int J Dermatol. 2014;53(11):1417-1422. doi:10.1111/ijd.12425

57. Martín Gutiérrez F, Ortega Resinas M, Camacho Martínez F. Fototerapia UVB en la micosis fungoide [UVB phototherapy in mycosis fungoides]. Actas Dermosifiliogr. 2000;91(3):98-100.

58. Herrmann JJ, Roenigk HH, Hurria A, et al. Treatment of mycosis fungoides with photochemotherapy (PUVA): long-term follow-up. J Am Acad Dermatol. 1995;33(2):234-242. doi:10.1016/0190-9622(95)90241-4

59. Ponte P, Serrão V, Apetato M. Efficacy of narrowband UVB vs. PUVA in patients with early-stage mycosis fungoides. $J$ Eur Acad Dermatology Venereol. 2010;24(6):716-721. doi:10.1111/j.14683083.2009.03500.x

60. Pavlotsky F, Barzilai A, Kasem R, Shpiro D, Trau H. UVB in the management of early stage mycosis fungoides. JEur Acad Dermatology Venereol. 2006;20(5):565-572. doi:10.1111/j.1468-3083.2006.01557.x

61. Brazzelli V, Antoninetti M, Palazzini S, Prestinari F, Borroni G. Narrow-band ultraviolet therapy in early-stage mycosis fungoides: study on 20 patients. Photodermatol Photoimmunol Photomed. 2007;23(6):229-233. doi:10.1111/j.1600-0781.2007.00314.x

62. Navi D, Riaz N, Levin Y, Sullivan N, Kim Y, Hoppe R. The Stanford University experience with conventional-dose, total skin electron-beam therapy in the treatment of generalized patch or plaque (t2) and tumor (t3) mycosis fungoides. Arch Dermatol. 2011;147 (5):561-567. doi:10.1001/archdermatol.2011.98

63. Quirós PA, Jones GW, Kacinski BM, et al. Total skin electron beam therapy followed by adjuvant psoralen/ultraviolet-A light in the management of patients with T1 and T2 cutaneous T-cell lymphoma (mycosis fungoides). Int $J$ Radiat Oncol Biol Phys. 1997;38(5):1027-1035. doi:10.1016/S0360-3016(97)00127-2

64. Jones GW, Tadros A, Hodson DI, Rosenthal D, Roberts J, Thorson B. Prognosis with newly diagnosed mycosis fungoides after total skin electron radiation of 30 or 35 GY. Int J Radiat Oncol Biol Phys. 1994;28(4):839-845. doi:10.1016/0360-3016(94)90103-1

65. Elsayad K, Kriz J, Moustakis C, et al. Total skin electron beam for primary cutaneous T-cell lymphoma. Int J Radiat Oncol Biol Phys. 2015;93(5):1077-1086. doi:10.1016/j.ijrobp.2015.08.041

66. Kamstrup MR, Gniadecki R, Iversen L, et al. Low-dose (10-Gy) total skin electron beam therapy for cutaneous T-cell lymphoma: an open clinical study and pooled data analysis. Int J Radiat Oncol Biol Phys. 2015;92(1):138-143. doi:10.1016/j.ijrobp.2015.01.047

67. Hoppe RT, Harrison C, Tavallaee M, et al. Low-dose total skin electron beam therapy as an effective modality to reduce disease burden in patients with mycosis fungoides: results of a pooled analysis from 3 phase-II clinical trials. J Am Acad Dermatol. 2015;72 (2):286-292. doi:10.1016/j.jaad.2014.10.014

68. Zackheim H, Kashani-Sabet M, Amin S. Topical corticosteroids for mycosis fungoides: experience in 79 patients. Arch Dermatol. 1998;134(8):949-954. doi:10.1001/archderm.134.8.949

69. Zackheim HS. Treatment of patch-stage mycosis fungoides with topical corticosteroids. Dermatol Ther. 2003;16(4):283-287. doi:10.1111/j.13960296.2003.01639.x

70. Centro de información online de medicamentos (Aemps - CIMA) [Medicine online information center of AEMPS - CIMA]. Ministerio de Sanidad Consumo y Bienestar Social. Available from: https:// cima.aemps.es. Published 2018. Accessed November 22, 2018.

71. Andía AA. Corticoides tópicos [Topical corticosteroids]. Boletín Inf Farmacoter Navarra. 2001;9(2):1-13.

72. Abbott RA, Whittaker SJ, Morris SL, et al. Bexarotene therapy for mycosis fungoides and Sézary syndrome. Br J Dermatol. 2009;160 (6):1299-1307. doi:10.1111/j.1365-2133.2009.09037.x

73. Molin L, Thomsen K, Volden G, et al. Oral retinoids in mycosis fungoides and Sézary syndrome: a comparison of isotretinoin and etretinate. A study from the Scandinavian Mycosis Fungoides Group. Acta Derm Venereol. 1987;67(3):232-236. 
74. Molin S, Ruzicka T. Possible benefit of oral alitretinoin in T-lymphoproliferative diseases: a report of two patients with palmoplantar hyperkeratotic-rhagadiform skin changes and mycosis fungoides or Sézary syndrome. Br J Dermatol. 2009;161(6):1420-1422. doi:10.1111/ j.1365-2133.2009.09475.x

75. Sokołowska-Wojdyło M, Lugowska-Umer H, MaciejewskaRadomska A. Oral retinoids and rexinoids in cutaneous T-cell lymphomas. Postepy Dermatol Alergol. 2013;30(1):19-29. doi:10.5114/pdia.2013.33375

76. Whittaker S, Ortiz P, Dummer R, et al. Efficacy and safety of bexarotene combined with psoralen-ultraviolet A (PUVA) compared with PUVA treatment alone in stage IB-IIA mycosis fungoides: final results from the EORTC Cutaneous Lymphoma Task Force phase III randomized clinical trial. $\mathrm{Br} J$ Dermatol. 2012;167(3):678-687. doi:10.1111/j.1365-2133.2012.11156.x
77. Wozniak MB, Tracey L, Ortiz-Romero PL, et al. Psoralen plus ultraviolet $\mathrm{A} \pm$ interferon- $\alpha$ treatment resistance in mycosis fungoides: the role of tumour microenvironment, nuclear transcription factor- $\kappa \mathrm{B}$ and T-cell receptor pathways. Br J Dermatol. 2009;160(1):92-102. doi:10.1111/j.1365-2133.2008.08886.x

78. Rupoli S, Barulli S, Guiducci B, et al. Low dose interferon-alpha2b combined with PUVA is an effective treatment of early stage mycosis fungoides: results of a multicenter study. Cutaneous-T Cell Lymphoma Multicenter Study Group. Haematologica. 1999;84(9):809-813.

79. Rupoli S, Goteri G, Pulini S, et al. Long-term experience with low-dose interferon- $\alpha$ and PUVA in the management of early mycosis fungoides. Eur J Haematol. 2005;75(2):136-145. doi:10.1111/j.1600-0609.2005.00497.x

80. Hengge UR, Ruzicka T, Schwartz RA, Cork MJ. Adverse effects of topical glucocorticosteroids. J Am Acad Dermatol. 2006;54(1):1-15. doi:10.1016/j.jaad.2005.01.010

\section{Publish your work in this journal}

ClinicoEconomics and Outcomes Research is an international, peerreviewed open-access journal focusing on Health Technology Assessment, Pharmacoeconomics and Outcomes Research in the areas of diagnosis, medical devices, and clinical, surgical and pharmacologica intervention. The economic impact of health policy and health systems organization also constitute important areas of coverage. The manuscript management system is completely online and includes a very quick and fair peer-review system, which is all easy to use. Visit http://www.dovepress.com/testimonials.php to read real quotes from published authors. 